\title{
LANGUAGE LEARNING SKILLS RELATED PROBLEMS IN TEACHING TURKISH AS A FOREIGN LANGUAGE: THE CASE OF THE INTENSIVE COURSES OF LANGUAGES AT THE UNIVERSITY OF TLEMCEN, ALGERIA
}

\author{
Boukhatem Nadera \\ ESM superior school of Management, ALGERIA, boukhatem.nadera@yahoo.fr
}

\begin{abstract}
Teaching the Turkish language in Algeria has its potential problems due to the lack of authentic language input. Algeria is a foreign language context, and this hinders learners in mastering the Turkish language in a short time ( 6 months). Moreover, other problems caused by poor instructional planning contribute to this process negatively. With these potential hindrances, the present study aims to seek what other challenges incapacitate intensive courses teaching/learning of Turkish conducted with 80 students between 23 and65 years old. Data were collected using a semi-structured interview. Results show that poor institutional planning is the leading cause of challenges experienced by native Turkish teachers. Besides this, instructional and socio-cultural/economic problems are the other challenges for teaching Turkish.

Therefore, the utilization of visual and audial tools is useful in concretizing the learning process. Efforts to adapt some tools developed by our day's technology to the class environment have become of greater importance. Simultaneously, the increase in the number of approaches to developing students' communication and cross-cultural interaction is an indicator that audial and written tools are essential for foreign language teaching. The utilization of visual and audial tools is useful in concretizing the learning process.
\end{abstract}

Keyword: Teaching Turkish as a foreign language, Intensive courses at Tlemcen University, challenges, effective learning

\section{INTRODUCTION}

Many linguists have studied the difficulties and problems of learning and teaching Turkish as a foreign language as they face failure during the teaching or learning process. Considering the failure of teaching Turkish as a foreign language, there are different reasons: insufficient number of instructional units offered in Turkish courses per week, linguistic difficulties of both languages, lack of appropriate teaching materials, lack of skilled native speakers (just one teacher), and lack of linguistic theoretical basis (Eryılmaz, 1996). Cotukesen (1983) also states that Turkish learners as a foreign language have difficulty with suffocation, nominalizations, subject-verb agreement, adjective phrases, complex sentences, relative clauses, nominal cases, and derivational * Okutman, JagiellonianÜniversitesi. FilolojiFakültesi, Krakow suffixes.

There are other difficulties that the students also face mainly, with orthography, punctuation, intonation, pronunciation, pitch, and juncture. Aydın (1993) mentions the effect of positive and negative transfer, giving examples of the overuse of personal pronouns, lack of object-verb agreement.

There is a big gap and need in the field and subject of TTFL in Algeria. Hardly this idea has remained as a 
discussion and suggestion matter, and no concrete step has been taken about opening related departments.

\section{LITERATURE REVIEW}

\subsection{The Turkish Language}

The Turkish language has always been a significant language for historical reasons and due to its political, geographical, and economic position in the world. Thereupon, many universities have Turkish studies departments, and more people encounter the language every day and want to learn. It is spoken among a large well-dispersed group of people in Bulgaria, Romania, Greece, Cyprus, some Middle East countries, Germany, Holland, Belgium, Britain, and Australia. Nearly 125 million people speak Turkic languages across the world. Some of these languages are closely related to Turkish. Likewise, Turkish is the official language of the Turkish Republic, and spoken by more than 80 million people in the country and additionally about 5.5 million people who live in European countries, USA, Australia, Russia, and the Arab countries as well (Turkish Foreign Affairs data of 2015). Turkic world outstretches on a vast region from the Balkans to Mongolia. According to UNESCO's data, Turkish is among the most commonly spoken language all around the world. '(Ayşe DAĞ PESTIL ) 2016

The tradition of teaching, learning, and the use of the Turkish language and culture in Algeria date back to the establishment of the Ottoman period in Algeria in the 15 century. Throughout time, where Algerian and Turkish people married and shared the same culture. There are still many borrowed words from the Turkish language used in daily communication in the Algerian dialect. As an illustration :

\begin{tabular}{|c|c|}
\hline Turkish Words & English \\
\hline Chadi & Monkey \\
\hline Meryoul & Smutty \\
\hline Soukardji & Drunkard \\
\hline Gourbi & Hut \\
\hline Khourda & Flea market \\
\hline Cheffar & Pickpocket \\
\hline Zzawalli & Poor \\
\hline Rechta & Paste \\
\hline Bechma9 & Slipper \\
\hline Tbassa & Dishes \\
\hline Guæna & Also \\
\hline T9achær & Socks \\
\hline Bezzaf & A lot of \\
\hline Dolma & Meatballs \\
\hline Mengoucha & Earring \\
\hline
\end{tabular}

\section{METHODOLOGY}

\subsection{Research Design}

As perthe purpose of this exploratory study is to have a better understanding of the quantitative data results. We have collected the qualitative data via semi-structured interviews with volunteer students. Thus, we had an opportunity to provide a more in-depth analysis of the data by considering the students' ideas and perceptions with their statements.

\subsection{Participants}

This study included 80 students in a Turkish language learning program divided into two groups for beginners: elementary and the last group for intermediate. The study lasted six months, and for those who want to improve their language skills, they can add 80 hours as an internship in Istanbul (i.e., one month) with native teachers. The participants were male and female; their age was between 23 to 65years. They had no previous experience with the Learning of the Turkish language.

\subsection{Sample of the Research}

The sample of the study has been prepared by the teacher under the framework of vocabulary, grammar, reading, and writing taught in the 12 chapters of Lale Turkçe DersKitabi 1 Course Book (Öztürk\&Akçay, 2011).

The teacher used some traditional reading, question/answer approach, and Pair work questions. As an 
illustration, this is a dialogue completion. It was demonstrated that the experimental group students could remember the text learned by performing could be recollected well even after one week, especially those for greetings in the first chapter.

Asagidakiboşluklarıdiyalogagöredoldurunuz.

A: Hos geldiniz.

B:

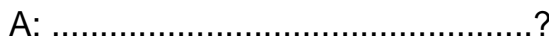

B: Osman.

A: ne?

B: Soyadım Kara. HOŞ GELDiNiz

A Dinleyinizveisaretleyiniz.

1. A: Merhaba

2. B: Merhaba

3. A: Adın ne?

4. B: Adım
A) Ayşe
B) Ebru
C) Sevgi

Besides, It has been demonstrated that performing dialogues have increased the motivation of the advanced group of students, and their self-confidence also increased since those students collaborate to compose a dialogue, which can later be performed for the entire class. They managed to speak the language they are learning while performing some during the warm upstage. While conducting some dialogues, the students could express themselves freely. This will facilitate the development of their speaking skills on a more advanced level of Turkish. The teachers were very impressed. They should almost always prepare and hold lively and engaging activities to remove the monotonousness and attract their students' attention like visual aids. Learning can be reinforced with different teaching/learning resources because they stimulate, motivate, and focus learners' attention for a while during the instructional process. Visual aids arouse the interest of learners and help the teachers to explain the concepts easily. Visual aids are those instructional aids that are used in the classroom to encourage the teaching-learning process. As Singh (2005) defines: "Any device which by sight and sound increase the individual s' practice, outside that attained through reading labeled as an audiovisual aid."

Turkish teachers should use visual aids to help the teacher clarify, establish, and correlate and co-ordinate precise conceptions, understandings, and appreciations and support him to make learning more actual, active, motivating, and encouraging.

These devices help the teacher clarify, establish, and correlate and co-ordinate precise conceptions, understandings, and appreciations and support him to make learning more actual, active, motivating, encouraging, significant, and glowing. Indeed visual aids help students to acquire an accurate image when they see and hear correctly.

The correct use of visual aids helps to retain more concepts permanently and avoid misusing them.

Visual aids provide a complete example of conceptual thinking.

Visual aids create an environment of interest for the students.

Visual aids help to increase the vocabulary of the students.

Visual aids help the teacher to get some time and make learning permanent.

Visual aids provide direct experience to the students. ( Ghulam Shabiralyani,2015)

Visual aids are those instructional aids that are used in the classroom to encourage the teaching-learning process. As Singh (2005) defines: "Any device which by sight and sound increase the individual s' practice, outside that attained through reading labeled as an audiovisual aid." 


\section{THE DIFFICULTIES OF TEACHING THE TURKISH LANGUAGE}

There are a lot of challenges encountered in terms of the learners. According to Ercil (2003), a Turkish language instructor categorizes the problems into four groups:

1. Shortage of instructional materials, such as course textbooks and digital instructional materials.

2. Individual differences among students.

3. Students are learning activities outside the classroom.

4. Organization of the Turkish classes.

On the other hand, Turkish is different from their native language. In fact, it is an agglutinative Ural-Altaic language, which has different phonetics and structural characteristics (O "zyu "rek 2009). For example, in Turkish, the verb is at the end of the sentence, and there are many suffixes. Although it might be tough to learn for students who are not familiar with this type of language structure, many people in the world are increasingly learning and speaking Turkish (Ozyurek 2009)

\section{CONCLUSION}

While aware of the achievements, the results show that Turkish teachers observe many difficulties in implementing some methods in their classrooms. These difficulties stem from three directions: the teacher, the students, and the educational system. The results suggest that Turkish teachers are not somewhat optimistic about the complete adoption of new methods despite showing a keen interest in change. Thus, they feel that only by overcoming some difficulties and establishing more favorable conditions for implementing new strategies.

\section{REFERENCE LIST}

1. Aydın, O. (1993). TürkceninSözdizimineiliskinOlumsuzAktarımYanlışlari. DilDergisi, TOMER, Sayı:9.

2. Ayşe DAĞ PESTIL (2016) Teaching Turkish as a foreign language to the speakers of Russian language: historical background, publications and course materials, 64 - 131

3. Cotukesen, Y. (1983). YabancıDilOlarakTurkceOgretimi/ YabancilarinTurkceOgrenirkenKarsilastiklariGucluklerveYaptiklariYanlislar. Turk DiliSayi: 379-380.

4. Ercil, N (2003). An Electronic Performance Support System for Teaching Turkish as a Foreign Language: A Case Study. Unpublished PhD Thesis. METU, Ankara

5. Eryılmaz, E. (1996). Teaching Turkish as a Foreign Language: A Systems Approach Through Linguistic Perspective. Unpublished Ph.D. Thesis. Hacettepe University, Ankara.

6. GhulamShabiralyani, KhuramShahzadHasan Impact of Visual Aids in Enhancing the Learning Process Case Research: District Dera Ghazi Khan. (Paper) ISSN 2222-288X (Online) Vol.6, No.19, 2015227

7. Journal of Education and Practice www.iiste.org ISSN 2222-1735

8. Lale Turkçe DersKitabi 1 Course Book (Öztürk\&Akçay, 2011)

9. Ozyurek, R. (2009). The problems encountered in learning Turkish by international students of Turkic origin coming from Turkic states and communities to Turkish universities. Turkish Studies, 4(3), 18191862. https://doi.org/10.7827/TurkishStudies.759.

10.Singh (2005) ); Instructional Technology in Education, published by Darya ganj new Delhi. 